\title{
Cochorous olitorous and Adasonia digitata leaves extracts protects against gamma radiation induced anaemia
}

\author{
Sarah Onyenibe Nwozo $^{1^{*}}$ and Bello Kabir ${ }^{1,2}$ \\ ${ }^{1}$ Nutritional /Industrial Biochemistry Unit, Department of Biochemistry, Faculty of Basic Medical Sciences, College of Medicine, \\ University of Ibadan, Nigeria \\ ${ }^{2}$ Department of Biochemistry, Faculty of Basic Medical Sciences, University of Ilorin, Nigeria
}

\section{Article history}

Received: 24 May 2015

Accepted: 14 July 2015

Published online: 2 August 2015

(c) Nwozo \& Kabir (2015)

Publisher

Horizon e-Publishing Group

Keywords

Cochorous olitorious

Adasonia digitata

anti-anaemic hepatoprotective

radioprotective

Corresponding Author

Sarah Onyenibe Nwozo

$凶$ sonwozo@yahoo.com,

onyenibe.nwozo@mail.ui.edu.ng

\begin{abstract}
This paper proposes that exposure to radiation could generate free radicals, which could lead to disorders such as heamolysis-induced anaemia. We evaluated the radioprotective potentials of Cochorous olitorious and Adasonia digitata methanol leaves extract in gamma radiation induced anaemia. Fifty four adult male Wistar rats were divided into nine groups of 6 animals. Except for the control group, the other the animals were treated with a single dose of whole body gamma radiation of 6Gy and received either 500 or $1000 \mathrm{mg} / \mathrm{kg}$ body weight (bwt) of A. digitata and $C$. olitorious either singly or combination and vitamin $C$ was used as reference. A. digitata and $C$. olitorious were screened for phytochemical content and had saponin (16.59 \pm 1.85 and $22.12 \pm 0.24)$, tannins (311.98 \pm 0.01 and $287.07 \pm 0.16)$, polyphenols $(170.90 \pm 0.68$ and $330.07 \pm 0.32)$, alkaloids $(81.56 \pm 0.56$ and $68.65 \pm 2.05)$ and flavonoids $(25.38 \pm 2.88$ and $157.38 \pm 0.38)$ respectively. There was significant loss in body weight, depletion in red blood cells (RBC), packed cell volume (PCV), heamoglobin concentration (HBC) in untreated rats exposed to gamma radiation. Administration of the plant extract to rats exposed to radiation was able to attenuate and ameliorate loss in body weight and changes in blood cells (HBC, PCV, PLT and RBC) especially in radiated rats on combination therapy of both extracts at $1000 \mathrm{mg} / \mathrm{kg}$ bwt group. Hepatoprotective and safety evaluation was done by measuring the serum ALT, AST and ALP, these parameters were significantly $(p<0.05)$ increased in untreated rats exposed to gamma radiation compared to normal control rats and these decreased in rats on plant extract.
\end{abstract}

Nwozo, S. O. and Kabir, B. 2015. Cochorous olitorous and Adasonia digitata leaves extracts protects against gamma radiation induced anaemia. Plant Science Today 2(3): 102-106. http://dx.doi.org/10.14719/pst.2015.2.3.123

\section{Introduction}

Ionizing radiation and other radioactive sources of high electron leakages, produce free radicals, which could lead to deleterious conditions such as hemorrhage induced anaemia, cancer, ischemia reperfusion diseases, atherosclerosis, diabetes and several other pathological disorders (Haliwell and Gutteridge, 2000). Ionizing radiation initiates the formation of free radicals, with the potential to attacking molecular oxygen thus producing a variety of reactive oxygen species (ROS) (Sadani and Nadkarni, 1997; Anderson et al., 2001). These reactive species react with the biomolecules such as nucleic acids (DNA and RNA), mostly membrane proteins and lipids, resulting to chain of reaction leading to lipid peroxidation, protein oxidation and Nucleic acid-base breakage (Parihar et al., 2007). ROS in membranes could cause alterations to the integrity, fluidity, permeability and biological functions of membranes; while they could generate in low density lipoprotein (LDL) proatherogenic and proinflammatory response as well as generates toxic products (Greenberg et al., 2008). One of the pathological conditions resulting from human exposure to radiations is anaemia, a blood disorder which affects all age groups especially the elderly, pregnant, lactating women and infants been more susceptible. There are different types of anemia and all types lead to depletion in red blood cells (WHO, 1986; Ogbe et al., 2010). Iron deficiency is the most common cause of nutritional anaemia, a condition which affects over 600 million especially in low-income countries (Oladiji et al., 2007).

Corchorus olitorius (Linn) is a leafy vegetable that belongs to the family Tiliaceae, and is known as "Eewedu" and Krin-krin in South western and South Eastern, Nigeria. The leaves (either fresh or dried) are cooked into a thick viscous soup or added to stew or soup and are rich sources of vitamins and minerals (Branda et al., 2004). 
Nutritionally, $C$. olitorius on an average contain $85-87 \mathrm{~g}$ $\mathrm{H}_{2} \mathrm{O}, 0.7 \mathrm{~g}$ oil, $5 \mathrm{~g}$ carbohydrate, $1.5 \mathrm{~g}$ fiber, $250-266 \mathrm{mg}$ Ca, $4.8 \mathrm{mg} \mathrm{Fe}, 1.5 \mathrm{mg}$ vitamin A, $0.1 \mathrm{mg}$ thiamine, $0.3 \mathrm{mg}$ riboflavin, $1.5 \mathrm{mg}$ nicotinamide, and $53-100 \mathrm{mg}$ ascorbic acid per 100g (Branda et al., 2004). Leaves decoction is used for treating iron deficiency, folic acid deficiency, as well as treatment of anemia and as blood purifier, while the leaf twigs are used against heart troubles (Krivanek et al., 2007).

Adansonia digitata $\mathrm{L}$. is a tree found widely throughout Africa and known locally in African countries as the tree of life. A. digitata is commonly used traditional plant which are consumed in food or used in the direct treatment of several diseases such as cancer, anaemia, diabetes, ischemia reperfusion diseases, and inflammatory bowel syndrome in South-western Nigeria (Lewanda et al., 2007). The baobab tree is an important food, water and shelter source in many African countries (Byrd-Bredbenner et al., 2007). Chemical composition include tannins, phlorotannins, terpenoids, glycosides, saponin and terpenoids as well as antioxidants including flavonoids and polyphenols. Drying baobab leaves in the shade protects against deterioration of provitamin, other authors mention the carotenoid content of baobab leaves. This result is almost 1000 times lower than composition and nutritional value of baobab foods the one reported by Vertuani et al. (2002), content of flavonoids and other antioxidant (Krivanek, 2007).

These considerations led us to evaluate the effect of $C$. olitorous and A. digitata on rats exposed to radiotherapy and to compare the protective effect of individual plant extract, combined effect of administration of both extracts and to compare that with standard antioxidant drug Vitamin C.

\section{Materials and Methods}

\section{Plants materials}

The leaves of $C$. olitorous and $A$. digitata were purchased at Bodija market, Ibadan, Oyo State. The plants were identified and authenticated at the Forestry Research Institute of Nigeria (FRIN). Leaves were dried, ground into a coarse powder and 500g each of the plants macerated in $2000 \mathrm{ml}$ of methanol (solvent) for $72 \mathrm{~h}$. Extract was filtered and concentrated using rotatory evaporator, the percentage yield of $C$. olitorous was $4.6 \%$ and $A$. digitata was $14.8 \%$.

\section{Animals, radiation exposure and treatment}

Ninety adult male albino rats weighing $190-200 \mathrm{~g}$ were purchased from the Animal house of the Department of Physiology, University of Ibadan. These rats were initially acclimatized for a week in well-ventilated cages in Animal house of Department of Biochemistry. Rats had free access to water and rat feed bought from Ladokun Feeds, Mokola, Ibadan.

Animals in the irradiated groups were treated with samples, 1 week before radiation exposure and 1 week after radiation exposure. The animals were treated with a single dose of whole body gamma radiation of 6Gy. Last dose of sample administration was 24hours before irradiation whereas the feed was withdrawn 12hours before irradiation. The radiation exposure system was done at Radiotherapy Department, College of Medicine, $\mathrm{UCH}$, Ibadan. The animals were kept in an improvised cage to restrict their movement and to ensure uniform and effective exposure.

\section{Experimental design}

Fifty four adult male Wistar rats weighing between 190200g, were purchased in the Animal house of Department of Biochemistry, University of Ibadan, and was randomly selected and distributed into nine groups of 6 rats each. The designs of the 9 group members are given in Table 1 .

Table 1. Animal grouping and treatment

\begin{tabular}{|c|c|}
\hline Control & Non-irradiated, non-treated \\
\hline IR & Irradiated, non-treated (R) \\
\hline $\mathrm{IR}+500 \mathrm{mg} / \mathrm{kg}$ & $\begin{array}{l}\text { Irradiated animals treated with } 500 \mathrm{mg} / \mathrm{kg} \text { body } \\
\text { weight }\left(\mathrm{RE}_{1500}\right)\end{array}$ \\
\hline IR + 1000mg/kg & $\begin{array}{l}\text { Irradiated animals treated with } 1000 \mathrm{mg} / \mathrm{kg} \\
\text { body weight }\left(\mathrm{RE}_{11000}\right)\end{array}$ \\
\hline $\mathrm{IR}+500 \mathrm{mg} / \mathrm{kg}$ & $\begin{array}{l}\text { Irradiated animals treated with } 500 \mathrm{mg} / \mathrm{kg} \text { body } \\
\text { weight }\left(\mathrm{RE}_{2500}\right)\end{array}$ \\
\hline IR + 1000mg/kg & $\begin{array}{l}\text { Irradiated animals treated with } 1000 \mathrm{ml} / \mathrm{kg} \\
\text { body weight }\left(\mathrm{RE}_{21000}\right)\end{array}$ \\
\hline $\mathrm{IR}+500 \mathrm{mg} / \mathrm{kg}$ & $\begin{array}{l}\text { Irradiated animals treated with } 500 \mathrm{mg} / \mathrm{kg} \text { body } \\
\text { weight }\left(\mathrm{R} \mathrm{E}_{1+} \mathrm{E}_{2500}\right)\end{array}$ \\
\hline IR + 1000mg/kg & $\begin{array}{l}\text { Irradiated animals treated with } 1000 \mathrm{mg} / \mathrm{kg} \\
\text { body weight }\left(\mathrm{R} \mathrm{E}_{1+} \mathrm{E}_{2} \text { 1000) }\right.\end{array}$ \\
\hline IR + Vitamin C & $\begin{array}{l}\text { Irradiated animals treated with vitamin C (100 } \\
\mathrm{mg} / \mathrm{kg} \text { body weight) }\end{array}$ \\
\hline
\end{tabular}

\section{Phytochemical screening}

The phytochemicals such as flavonoids, tannins, saponins, alkaloids, polyphenols and anthraquionones were identified by chemical method and as modified by Harborne (1996) and Sofowora (1993).

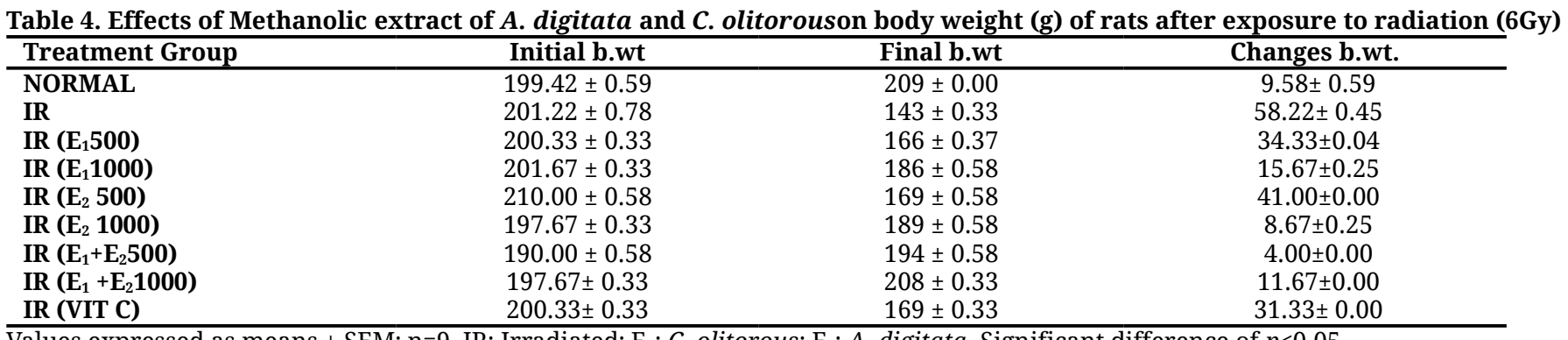

Values expressed as means $\pm \mathrm{SEM} ; \mathrm{n}=9$, IR: Irradiated; $\mathrm{E}_{2}$ : C. olitorous; $\mathrm{E}_{1}$ : A. digitata. Significant difference of $p<0.05$. 
Table 5. The heamatological analysis of rats exposed to radiation (6Gy) on methanolic extracts of A.digitata and C.olitorous.

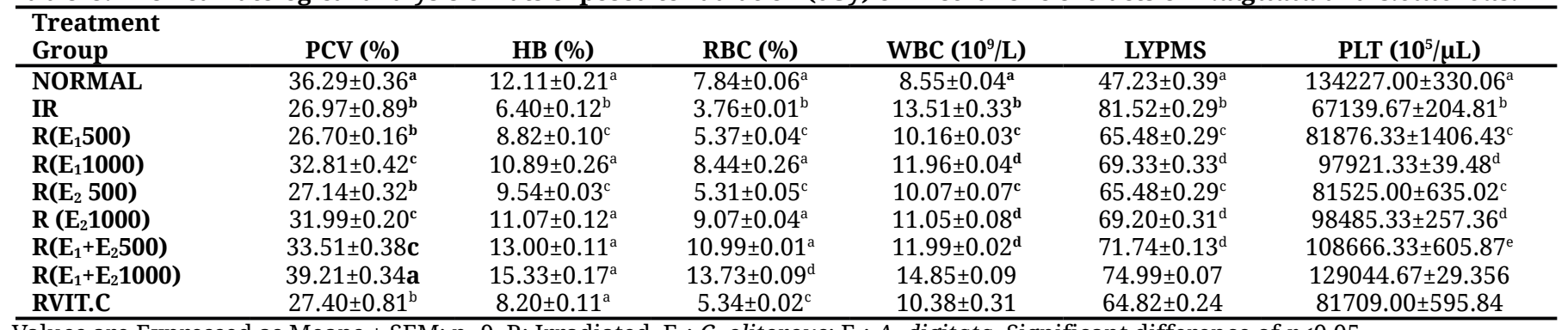

Values are Expressed as Means \pm SEM; $\mathrm{n}=9$, R: Irradiated, $\mathrm{E}_{2}:$ C. olitorous; $\mathrm{E}_{1}:$ A. digitata. Significant difference of $p<0.05$.

Table 6. Effect of methanolic extracts of A. digitata and C. olitorous on serum AST, ALT and ALP levels (U/L) of rats exposed to radiation (6Gy).

\begin{tabular}{|c|c|c|c|}
\hline Treatment Group & AST & ALT & ALP \\
\hline NORMAL & $95.39 \pm 0.89^{\mathrm{a}}$ & $58.23 \pm 0.51^{\mathrm{a}}$ & $24.68 \pm 0.16^{\mathrm{a}}$ \\
\hline IR & $143.33 \pm 0.89^{b}$ & $98.00 \pm 0.57^{\mathrm{b}}$ & $76.49 \pm 0.77^{b}$ \\
\hline$R\left(E_{1} 500\right)$ & $126.32 \pm 0.36^{c}$ & $72.71 \pm 0.16^{c}$ & $62.53 \pm 0.24^{c}$ \\
\hline$R\left(E_{1} 1000\right)$ & $101.58 \pm 0.27^{\mathrm{d}}$ & $53.15 \pm 0.45^{\mathrm{a}}$ & $46.15 \pm 0.57^{d}$ \\
\hline$R\left(E_{2} 500\right)$ & $121.37 \pm 0.71^{\mathrm{c}}$ & $69.89 \pm 0.23^{c}$ & $60.73 \pm 0.37^{c}$ \\
\hline$R\left(E_{2} 1000\right)$ & $98.34 \pm 1.03^{\mathrm{a}}$ & $57.73 \pm 0.37^{d}$ & $43.82 \pm 0.30^{\mathrm{d}}$ \\
\hline$R\left(E_{1}+E_{2} 500\right)$ & $87.26 \pm 0.50^{a}$ & $54.45 \pm 0.29^{\mathrm{a}}$ & $39.07 \pm 0.14 \mathrm{e}$ \\
\hline$R\left(E_{1}+E_{2} 1000\right)$ & $75.89 \pm 0.11^{\mathrm{e}}$ & $48.67 \pm 0.67^{\mathrm{e}}$ & $24.30 \pm 0.39^{\mathrm{a}}$ \\
\hline RVIT.C & $120.33 \pm 0.33^{c}$ & $66.67 \pm 0.88^{\mathrm{c}}$ & $60.00 \pm 0.58^{c}$ \\
\hline
\end{tabular}

Values are expressed as means \pm sem; $\mathrm{n}=9$, $\mathrm{R}$ : Irradiated, $\mathrm{E}_{2}:$ C. olitorous; $\mathrm{E}_{1}:$ A. digitata. Significant difference of $p<0.05$.

\section{Determination of hematological and biochemical parameters}

Whole blood was collected from the eyes by ocular puncture and were put in ethylenediamine tetracetate (EDTA) bottles. The packed cell volume or the haematocrit and White blood cell count (WBC) was determined by the method of Baker and Silverton (1985), Hemoglobin (Hb) concentration was determined using the cyanomethemoglobin method (Jain, 1986) while platelets were determined by following the method of Mitruka and Rawnsley, (1997).

\section{Determination of serum enzyme assay}

Alanine transaminase (ALT) and aspartate transaminase (AST) activities and alkaline posphatase (ALP) serum level was estimated were determined using the Randox kits by Cypress diagnostics (Belgium).

\section{Statistical analysis of data}

Results was expressed with confidence interval as mean \pm standard deviation and were analyzed using the Analysis of Variance 'ANOVA, F-ratio and student's $t$ test where applicable. Values of $P \leq 0.05$ were regarded as significant in comparison with appropriate controls.

\section{Results and Discussions}

Table 2 shows the results of qualitative phytochemical screening of methanolic leaf extract and the presence of Saponin, alkaloids, flavonoids, polyphenols, tannins and terpenoids were detected. Anthraquinone, cardiac glycosides and phlobatannins were not found in $C$. olitorious and $A$. digitata. Quantitative phytochemical screening showed that tannins and polyphenols were the most abundant phytochemicals present in both leaf extracts as shown on Table 3. Alkaloids have shown efficient therapeutic properties asan anticancer, analgesic, antispasmodic and antibacterial properties (Yakubu et al., 2009; Branda et al., 2004). Both natural and synthetic alkaloids have been used as basic medicinal agent. Polyphenol have been shown to be responsible for the induction of several phase-2 (Farombi and Shur, 2006).

Table 2. Qualitative phytochemical screening

\begin{tabular}{lcc}
\hline Metabolites & $\begin{array}{c}\text { Adasonia } \\
\text { digitata }\end{array}$ & $\begin{array}{c}\text { Corchorus } \\
\text { olitorius }\end{array}$ \\
\hline Alkaloids & ++ & ++ \\
Anthraquinone & - & - \\
Cardiarc glycosides & - & + \\
Flavonoids & ++ & ++ \\
Polyphenols & ++ & ++ \\
Phlobatanins & - & - \\
Saponin & ++ & ++ \\
Taninn & +++ & ++ \\
Terpenoids & + & ++ \\
Steriods & + & + \\
\hline
\end{tabular}

+: Faintly Present ++: Moderately Present +++: Excessively Present -: Absent

Table 3. Quantitative phytochemical screening

\begin{tabular}{llc} 
Metabolites & Adasonia digitata & $\begin{array}{l}\text { Corchorus } \\
\text { olitorius }\end{array}$ \\
\hline Alkaloids & $81.56 \pm 0.56$ & $68.65 \pm 2.05$ \\
Saponin & $16.59 \pm 1.85$ & $22.17 \pm 0.24$ \\
Tanins & $311.98 \pm 0.01$ & $287.07 \pm 0.16$ \\
Flavonoids & $25.38 \pm 2.88$ & $157.38 \pm 0.38$ \\
Polyphenols & $170.90 \pm 0.68$ & $330.07 \pm 0.32$ \\
\hline
\end{tabular}

Changes in body weight (bwt) changes in observed in rats in this study is shown on Table 4. Initially the bwt of the rats was 190-200g, but the untreated radiated rats had loss in weight of over 50g. Generally all animals exposed to gamma radiation had loss in bwt but animals on treatment with either vitamin $C$ and plant extract all gained weight with animals on $C$. olitorious and A. digitata combination therapy at $1000 \mathrm{mg} / \mathrm{kg}$ bwt having similar weight gain as the control rats that was not exposed to gamma radiation.

Heamatological parameters for rats on $C$. olitorious and $A$. digitata methanol extract exposed to gamma radiation 
is shown on Table 5. Untreated radiated rats had significantly decreased PCV, heamoglobin concentration and red blood cells, while platelets, lymphocytes and white blood cells compared to control un-radiated rats. Treatment with plant extract significantly attenuated the deleterious effects of irradiation, especially in animals on $1000 \mathrm{mg} / \mathrm{kg}$.

For the biochemical parameters in the Table 5, statistical analysis showed that the methanolic leaf extract of $C$. olitorous and $A$. digitata recorded a significant $(P=.05)$ increase for total proteins level for all treatment groups; C (60.20 \pm 0.46$), \mathrm{D}(68.97 \pm 0.23)$, and $\mathrm{E}(60.40 \pm 0.30), \mathrm{F}$ (70.14 \pm 0.10$), \mathrm{G}(59.85 \pm 0.20), \mathrm{H}(79.63 \pm 0.80)$, I $(67.89 \pm 3.90)$ when compared with negative control B $(54.10 \pm 0.58)$. But as observed in the Bilirubin and the MDA level which reduces upon extract administration when compared with the negative control groups that was exposed to radiation but not treated with the plant extracts.

Saponin has been established by Yakubu et al (2007) to prevent heamoglobin and platelets aggregation and protein oligomerization because saponin containing herbs have been successfully used in the management of liver inflammation, Polyphenol in the plant extracts has shown free radical scavenging free radicals and flavonoid have shown ability to prevent oxidative stress induced diseases (Kryston et al., 2011).

Free radicals has the potentials to attack iron containing proteins like heamoglobin resulting to the formation of a disulfide bonds, which disrupt protein structure giving rise to abnormal heamoglobin known as Heinze body. This in combination with other membrane and cytosolic proteins could trigger phagocytic degradation, resulting into iron loss, reduction in the RBC level and parked cell volume, all are pointers to anaemia. There was significant reduction in the PCV, RBC, HBC and PLT level in untreated rats exposed to radiation, when compared to the normal control group, this is suggestive of the effect of free radicals generated from radiation attacked on heamoglobin for destruction resulting into altered heamoglobin culminating anaemia. However, the administration of the methanolic extracts of $C$. olitorous and $A$. digitata on the anaemic irradiated rats was able to ameliorate the decrease in PCV, RBC, PLT and HBC as shown on Table 5 . The Table 5 shows that upon extracts administration, the PCV, HB, RBC and PLT level that was initially reduced significantly $(P<0.05)$ in the negative control group when compared with positive control group was significantly $(P<0.05)$ increased. There was significant $(P>0.05)$ reduction in white blood cell count (WBC) on the radiated groups co-treated with plant extract and this could be due to the presence of bioactive agents like polyphenols, flavonoids and tannins as shown on Tables 1 and 2 which have been implicated in free radical scavenging (Oyedeji et al., 2013).

Radiation increased the activities of AST, ALT, and ALP significantly and these were attenuated by administration of $C$. olitorius and A. digitataon either singly or the combination treatment as shown on Table 6 . The high level of ALT, AST and ALP in the serum is an indication of the degree of damages to the liver caused by the radiation. This is in agreement with the work of Albano, (2002) and Cederbaum, (2009) that rise in transaminase is an indication of severe hepatotoxicity thus allowing their escape from the tissues. The reduction in the levels of ALT,
AST and ALP activity in the groups co-administered with $C$. olitorious and $A$. digitata at 500 and $1000 \mathrm{mg} / \mathrm{kg}$ may be due to the phytochemicals present in the plant extracts such as the flavonoids and polyphenols (Arteel, 2003).

For AST levels, the extract recorded a significant $(P=.05)$ decrease for all treatment groups; C (126.32 \pm 0.36$)$, D (101.58 \pm 0.27$), \quad$ E $(121.37 \pm 0.71), \quad$ F $\quad(98.34 \pm 1.03), \quad G$ (87.26 \pm 0.50$) \mathrm{H}(75.89 \pm 0.11) \mathrm{I}(120.33 \pm 0.33)$ when compared with negative control B $(143.33 \pm 0.89)$. Similar trend were also observed in ALT and ALP levels. The Group 9 (Vitamin C treated group) was able to compete with the plant extract for treatment of irradiation induced anaemia at $500 \mathrm{mg} / \mathrm{kg}$ body weight, but above this concentration (1000 $\mathrm{mg} / \mathrm{kg}$ ) the combination therapy of $C$. olitorious and $A$. digitata had better effect than ascorbic acid. In conclusion $C$. olitorious and $A$. digitata extracts at $1000 \mathrm{mg} / \mathrm{kg}$ bwt showed better therapeutic efficacy when compared to 500 $\mathrm{mg} / \mathrm{kg}$ bwt and combination of both plants $(500 \mathrm{mg} / \mathrm{kg}$ and $1000 \mathrm{mg} / \mathrm{kg}$ bwt) was efficacious more than ascorbate alone.

\section{Competing interests}

The authors declare that they have no competing interests.

\section{Acknowledgments}

We are grateful to Mr Eric Sabo of Biochemistry Department, University of Ibadan and the technical staff in the Radiotherapy Department, College of Medicine, UCH, Ibadan, for technical assistance.

\section{References}

Albano, E. 2002. Free radical mechanism in immune reactions associated with alcoholic liver disease. Free Radic Biol Med 32:110-114. http://dx.doi.org/10.1016/S0891$\underline{\text { 5849(01)00773-0 }}$

Anderson, F. R., Fisher, J. L., Hara, Y., Harris, T., Mak, B. W., Melton, D. L. and E. J. Packer. 2001. Green tea catechins partially protect DNA from $\mathrm{OH}$ radical-induced strand breaks and base damage through fast chemical repair of DNA radicals. Carcinogenesis 22:1189-1193.

Arteel G. E. 2003. Oxidants and Antioxidants in Alcohol-Induced Liver Disease. Gastroenterology 124:778-790 http://dx.doi.org/10.1053/gast.2003.50087

Baker, F. J., and Silverton, R. E. 1985. Introduction to medical laboratory technology. $6^{\text {th }} \mathrm{Ed}$. Butterworth-Heinemann Ltd, London.

Branda, R. F., Naud, S. J., Brooks, E. M., Chen, Z., and Muss, H. 2004. Effect of vitamin B12, folate, and dietary supplements on breast carcinoma chemotherapy-induced mucositis and neutropenia. Cancer 101(5):1058-1064. http://dx.doi.org/10.1002/cncr.20484

Byrd-Bredbenner, C., Moe, G., Beshgetoor, D. and Berning, J. 2007. Wardlaw, Hampl \& DiSilvestro. Perspective in Nutrition. $8^{\text {th }}$ Ed, The McGraw Hill Companies.

Cederbaum, A. L., Lu, Y. and Wu, D. 2009. Role of oxidative stress in alcohol-induced liver injury. Arch Toxicol 83:519-548. http://dx.doi.org/10.1007/s00204-009-0432-0

Farombi, E. O., Surh, Y. 2006. heme oxygenase-1 as a therapeutic target for hepatoprotection. J. Biochem \& Molecular Biology 39(5): $479-491$. http://dx.doi.org/10.5483/BMBRep.2006.39.5.479

Greenberg, M. E., Li, X. M., Gugui, B. G., Gu, X. Qjn, J., Salomon, R. G. and Gazen, S. L. (2008). The lipid Whisker model of the structure of oxidized cell membranes, $J$ Biol Chem.238:2385 http://dx.doi.org/10.1074/jbc.M707348200

Halliwell, B., and Gutteridge, J. M. C. 2000. Free radicals in Biology and Medicine Oxford. Oxford University Press.

Harborne, J. B. 1973. Phytochemical Methods: A guide to modern techniques of plant analysis. Chapman and hall, London, pp. 279 
Jain, N.C. (1986) Schalm's veterinary heamatology, $4^{\text {th }}$ ed., Lea and fabiger, Philadephia.

Krivanek, A. F., De Groote, H., Gunaratna, N. S., Diallo, A. O. and Friesen, D. 2007. Breeding and disseminating quality protein maize (QPM) for Africa. Afr. J. Biotechnol.,6(4):312324.

Kryston, T. B., Georgiev, A. B., Pissis, P., Geogakrias, A. G. 2011. The role of oxidative stress and DNA damage in human carcinogenesis. Mutat. Res. 711: 193-201. http://dx.doi.org/10.1016/j.mrfmmm.2010.12.016

Lawenda, B. D., Smith, D. E., Xu, L., Niemierko, A., Silverstein, J. R., Boucher, Y., Kashiwagi, S., Held, K. D., Jain, R. K., Loeffler, J. S., Eisenberg, D. M.and Blumberg, J. B. 2007. Do the dietary supplements epigal-locatechin gallate or vitamin e cause a radiomodifying response on tumors in vivo? A pilot study with murine breast carcinoma. J. Soc Integr Oncology 5(1): 11-17. http://dx.doi.org/10.2310/7200.2006.033

Mitruka, B. M., Rawnsley, H. M. 1997. Clinical, Biochemical and heamatological reference values in normal experimental animal. Masson Publisher Co, New York, pp+ 102-107

Ogbe, R. J., Adoga, G. I., Abu, A. H. 2010. Antianaemic potentials of some plant extracts on pheny hydrazine-induced anaemia in rabbits. J Med Plants Res. 4(8): 680-684

Oladiji A. T., Jacob, T. O., Yakubu, M. T. 2007. Anti-anaemic potentials of aqueous extracts of Sorghum bicolor (L.) moench srem bark in rats. J. Ethopharmacology 111: 651656. http://dx.doi.org/10.1016/j.jep.2007.01.013

Oyedeji, K. O., Bolarinwa, A. F., Azeez, A. A. 2013. Effect of methanolic extract of Vernonia amygdalena on reproductive parameters in male albino rats. Res $J$ Pharmacology 7(1): 7-11.

Parihar, V. K., Dhawan, J., Kumar, S., Manjula, S. N., Subramanian, G., Unnikrishnan, M. K. and Rao, C. M. 2007. Free radical scavenging and radioprotective activity of dehydrozingerone against whole body gamma irradiation in Swiss albino mice. Chem Biol Interact 170(1):49-58. http://dx.doi.org/10.1016/j.cbi.2007.07.006

Sadani, G. R. and Nadkarni, G. D. 1997. Changes in lipid peroxide levels and the activity of reactive oxygen scavenging systems in thyroid tissue after exposure to radioactive iodine in rats. Thyroid. P937. http://dx.doi.org/10.1089/thy.1997.7.937

Sofowora, A. 1993. Medicinal plants and traditional medicine in Africa, second ed. Spectrum Books Limited (Publisher). Ibadan, Nigeria. Pp 134-156

Vertuani, S., Braccioli, E., Buzzoni, V., Manfredini, S., et al. 2002. Antioxidant capacity of Adansonia digitata fruit pulp and leaves. Acta Phytototherapeutica 2: 86-91

WHO, 1986. Use and interpretation of anthropometric indicators of nutritional status. Bull. World Health Organ.,64:924-941.

Yakubu, M. T., Akanji, M. A., Oladiji, A. T. 2007. Heamatological evaluation in male albino rats following chronic administration of aqueous extract of Fadogia agrestis stem. Pharmacol Manage. 3: 34-38.

Yakubu, M. T., Bukoye, B. B., Oladiji, A. T. Akanji, M. A. 2009. Toxicological implication of aqueous extract of Banbusa vulgaris leaves in pregnant Dutch rabbits. Human \& Exp. Toxicol. 28(9):

591-593. http://dx.doi.org/10.1177/0960327109106975

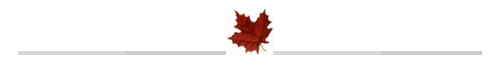

